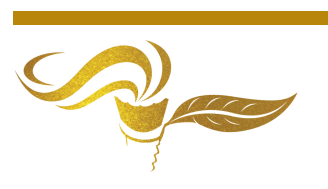

\title{
The impact of the Covid-19 Pandemic on the Mental Health and Socio-Economic Conditions of the Portuguese People
}

\section{André Leiria ${ }^{1}$ and Paulo Martins ${ }^{2}$}

${ }^{1}$ M.Sc (ISPA), student in Science of Religions (ULHT), Portugal, E-mail: andreleiria@hotmail.com

2 M.Sc (IST), Ph.D (UNL), CIUHCT-UNL, CTEC-UFP, Portugal, E-mail: paulonunom@gmail.com

* Correspondence: Email: paulonunom@gmail.com

Received 12 December, 2020; Revised 8 January, 2021; Accepted 11 January 2021

Available online 12 January, 2021 at www.atlas-journal.org, doi: 10.22545/2021/00151

\section{Short Letter}

Recently, several studies have been published on the impact of confinement (due to the Covid-19 pandemic) on the mental health of the Portuguese people [1]. For example, the Instituto de Psicologia Clínica e Forense (Institute of Forensic Psychology) carried out a study with 10,500 participants from the general Portuguese population, and found that $49.2 \%$ of them showed "moderate or severe" psychological impacts. Many of these people reported no mental disorders prior to the pandemic. Women were the group most susceptible to presenting some of the psychological symptoms mentioned above [2]. These investigations support others works on the impact of socioeconomic crises on the mental health of Portuguese people, which have shown that there is a relationship between the increase in symptoms of anxiety and depression and a decrease in well-being due to job insecurity, loss of income, unemployment and social isolation [3]. We should also note the effects of the pandemic (e.g., high mortality, decreased sleep hours, rationing of equipment for personal protection, etc.) on health professionals (doctors, nurses, diagnostic technicians), during the fight against Covid-19 in Portugal, where it has been shown that $72 \%$ of these professionals have medium or high levels of physical and/or psychological exhaustion, identical to "burnout". During non-pandemic times, this value is between $21 \%$ and $47 \%$ [4]. Furthermore, due to the pandemic, Portugal experienced an increase in mortality. The age group most affected was those 65 years or older [5].

Related to the above, for reasons of public health due to the pandemic, some sectors of activity in Portugal suffered an abrupt drop in their income (with values varying according to the sector). Catering and tourism, the clothing industry and transport services (aviation), among others, were placed in a fragile situation. This affected about $30 \%$ of the total active labor force in Portugal. The affected companies sought to minimize the situation through simplified lay-offs and the temporary suspension of employment 
André Leiria and Paulo Martins

The impact of the Covid-19 Pandemic on the Mental Health and Socio-Economic Conditions of the Portuguese People

contracts. Thus, at the end of April 2020, absolute unemployment in Portugal increased by $22 \%$ compared to the same time one year previously. The most-affected age group was that of young people (especially among those with a low level of education), who had great difficulty in finding their first employment contract or who saw their precarious contract not renewed [6]. The generalization of teleworking has been an alternative form of work adopted by many companies during the confinement as a means of combatting unemployment. Thus, while in 2019 only $6.5 \%$ of workers in Portugal were in a teleworking situation, since the beginning of the pandemic, the number has grown from $17 \%$ (in the case of micro companies) to $74 \%$ (in the case of large companies) [7]. It should be also noted that families with school-age children began to use internet and television broadcasts as ways to attend classes at a distance.

\section{References}

[1] Afonso P. (2020). O Impacto da Pandemia COVID-19 na Saúde Mental. Acta Médica Portuguesa, 33(5)=351-358. (doi:10.20344/amp.13877) [It could be complemented with the reading of Novais P. (2020). Covid-19. Estudo avalia impacto do isolamento social em adultos e idosos. O Observador. https://observador.pt/2020/10/12/covid19-estudo-avalia-impacto-do-isolamento-social-em-adultos-e-idosos. (Download on 14th November 2020).

[2] Paulino M., Dumas-Diniz R., Brissos S., Brites R., Alho L., Simões R., Silva F. (2020). COVID-19 in Portugal: exploring the immediate psychological impact on the general population. Psychology, Health \& Medicine, 1-12. (doi:10.1080/13548506.2020.1808236).

[3] OPP - Ordem dos Psicólogos Portugueses (2020). Crise Económica, Pobreza e Desigualdades. Relatório sobre Impacto Socioeconómico e Saúde Mental em Portugal. Lisboa.https://www.ordemdospsicologos.pt/ficheiros/documentos/crise_econaomica_pobreza_e_desigualdades. pdf. (Download on 10th November 2020).

[4] Escola Nacional de Saúde Pública (2020). Resultados do Questionário 2: Os riscos para os Profissionais de Saúde vão muito para além do vírus. Barómetro Covid-19. Universidade Nova de Lisboa. https://barometrocovid-19.ensp.unl.pt/resultados-do-questionario-2-os-riscos-para-os-profissionais-de-saude-vao-muito-paraalem-do-virus/. [It could be complemented with the reading of Marôco J., Marôco A., Leite E et al (2016). Burnout in Portuguese Healthcare Professionals: An Analysis at the National Level. Acta Med Port, 29(1): 24-30.https://research.unl.pt/ws/portalfiles/portal/3643300/Maroco_Acta_Med_Port_2016_29_1_24.pdf. (Download on 15th November 2020).

[5] Nogueira J., Nobre A., Nicola J., Furtado C., Carneiro A. (2020). Excess Mortality Estimation during the COVID-19 Pandemic: Preliminary Data from Portugal. Acta Médica Portuguesa, 33(6)=376-383. (doi:10.20344/amp.13928).

[6] Mamede R., Pereira M., Simões A. (2020). Portugal: Uma Análise Rápida do Impacto da Covid-19 na economia e no mercado de trabalho. Lisboa. Relatório da Organização Internacional de Trabalho. https://www.ilo.org/wcmsp5/ /groups/public/ - europe/-ro-geneva/—ilo-lisbon/documents/publication/ /wcms_754606.pdf (Download on 15th November 2020).

[7] Estatística Instituto Nacional de Estatística, Banco de Portugal (2020). Teletrabalho e presença alternada nas instalações da empresa na primeira quinzena de Julho de 2020 e evolução desde Abril. Inquérito Rápido e Excecional ás Empresas - COVID-19. https://www.bportugal.pt/sites/default/files/anexos/documentosrelacionados/iree_20200729.pdf (Download on15th November 2020).

Funding: This short letter received no external funding.

Conflicts of Interest: The authors declares no conflict of interest.

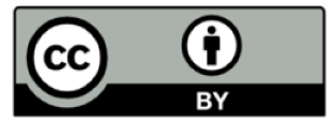

Copyright (C) 2021 by the authors. This is an open access article distributed under the Creative Commons Attribution License (https://creativecommons.org/licenses/by/4.0/), which permits unrestricted use, distribution, and reproduction in any medium, provided the original work is properly cited. 


\section{About the Authors}

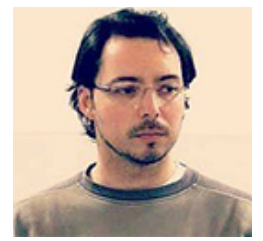

André Leiria has a degree in clinical psychology (Instituto Universitário de Ciências Psicológicas, Sociais e da Vida acronym for Instituto Superior de Psicologia Aplicada) and has a special interest in the psychology of religion and spirituality. Thus, he was a student of Science of Religions (Universidade Lusófona de Humanidades e Tecnologia de Lisboa), an area he intends to continue to develop through research. He is currently doing his specialization in Transpersonal Psychotherapy at Alma Soma Instituto Transpessoal (https://almasoma.pt/).

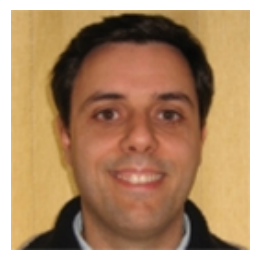

Paulo Nuno Martins is a Chemical Engineer (Instituto Superior Técnico, University of Lisbon) and PhD in History and Philosophy of Science, specialization in Epistemology of Science (Faculdade de Ciências e Tecnologia, New University of Lisbon). He has studied for 4 years Eastern languages and culture (Japanese, Chinese, Arabic) and he is currently a researcher at Interuniversity Center for History of Science and Technology, New University of Lisbon (CIUHCT-UNL) and Transdisciplinary Center for Consciousness Studies, University Fernando Pessoa of Oporto (CTEC-UFP), with ORCID: http://orcid.org/0000-0002-2670-3172. He is a member of CIRET (Centre International de Recherches et d'Études Transdisciplinaires), Paris. 